\title{
ECONOMY AND IDENTITY: FELT MAKING AND MARKETING IN KASHGAR1 REGION AND KONYA
}

\author{
[Araştırma Makalesi-Research Article]
}

\author{
Mukaidaisi MUHETAER*
}

Geliş Tarihi: 20.11.2020

Kabul Tarihi: 16.12.2020

\begin{abstract}
Kashgar in China and Konya in Turkey are centers of felt making. The making and marketing of felt in these places, however, developed in two different directions. In Konya felt is a sought-after tourism item while in Kashgar felt is reserved for personal use in a rural context. This paper is analyzing why felt making in Kashgar barely survived, while the felt industry in Konya flourished. The paper compares the processes of felt making, as well as the living or working conditions of felt makers in the two regions and argues that in Kashgar, felt is not only used for domestic purposes, but it is also a marker of Uyghur identity. Moreover, Kashgar is a historical center of Uyghur handicrafts and felt-making that had, due to the severe travel restrictions during the past centuries, little cultural exchange with other regions and the felt making techniques and production patterns thus barely changed. The limited flow of people, skills, ideas, and techniques reviles in a low marketability of felt in Kashgar and Uyghur felt makers hardly reach their level of subsistence by focusing on felt making. In contrast, Konya is a tourist's city and contemporary center of felt industry producing for tourists hunting local felt and felt products. As such, the Turkish felt makers incorporated modern patterns, eased, and accelerated the production process and in doing so repurposed the use felt, making it attractive for a young clientele. In this way they were able to cure prosperity for their felt industry.
\end{abstract}

Keywords: Kashgar, Konya, Industrialization, Repurposing of Felt, Felt Economy.

\section{EKONOMİ VE KIMLİK: KONYA VE KAŞGAR BÖLGESINDDE KEÇE YAPIMI VE PAZARLAMASI}

\section{$\ddot{O} z$}

Çin'de Kaşgar, Türkiye'de ise Konya keçe üretim merkezidir. Ancak bu iki yerdeki keçe yapımı ve pazarlaması oldukça farklı yönlere doğru ilerlemiştir. Konya'da keçe ise turizm ürünüyken Kașgar'da keçe kırsal bölgelerde kișisel kullanım ürünüdür. Bu makale, Konya'daki keçe endüstrisi gelişirken Kaşgar'daki keçeciliğin neden zor durumda kaldığını analiz etmektedir. Makalede, iki bölgedeki keçe yapım süreçleri ve keçe üreticilerinin yaşam ve çalışma koşulları karşılaştırılmıştır. Kaşgar'da keçe sadece ev içinde kullanılarak Uygur kimliğinin göstergesi olarak hizmet etmektedir. Üstelik Kaşgar, Uygur sanatkarları ve keçeciliğin tarihi merkezi olarak geçen yüzyıllardaki seyahat kısıtlamalarından dolayı diğer bölgelerle çok az kültürel alışveriş yapmış ve bu nedenle keçe yapım teknikleri ve üretim şekilleri neredeyse hiç değișmemiștir. Insanların, ipeklerin, fikirlerin ve tekniklerin sınırlı akışı, Kaşgar'daki keçeciliğin düşük düzeydeki pazarlanmasını yansıtmaktadır. Uygur keçe yapımcıları sadece keçe yapımına odaklanmış, geçim kaynaklarıyla hiç uğraşmamıştır. Buna karşı, Konya ise bir turizm şehri, yerel keçe ve keçe ürünlerini arayan turistler için üretim yapan bir çağdaş keçe endüstrisi merkezidir. Türk keçe üreticileri modern desenleri uygulamış, üretim sürecini kolaylaştırmış ve hızlandırmıștır. Böylece keçeyi farklı amaçlara uygulayarak genç müșterilerin ilgisini çeken ürün haline getirmiştir. Böylelikle keçe endüstrisinin gelişimini sağlamıştır.

*M. A., Department of Asian Studies, Palacky University in Olomouc, e-mail: mukaidaisi.muhetaer@upol.cz Orcid: Orcid: 0000-0001-5363-1007

1 What we mean Kashgar here is not only the Kashgar city itself but also its surrounding towns. 
Anahtar Kelimeler: Kaşgar, Konya, Sanayileşme, Yeniden Kullanım, Keçe Ekonomisi.

\section{Introduction}

From 2014 to 2017 I had the honor to study at Xinjiang University in Ürümqi, where my thesis supervisor was Rahile Dawut. To me, she was not only an academic mentor, but also a skilled life coach. During those three years, when she supervised my master thesis, she shared her inexhaustible knowledge and experiences with me. She taught me be an ethically guided and emotionally intelligent researcher. Rahile Dawut dedicated her own career to study and protect Uyghur folklore with felt as a central object. For her, the felt was more than a rural handicraft, it was a carrier of culture. To better understand the felt as a part of the culture, she initiated a research project called "Kashgar felt and its marketing" in 2014.

When studying under her supervision, I had an opportunity to join the research project and collected great amount of data for my thesis Marketing of Felt and Felt Technique in Kashgar. My master thesis illustrated the current situation of felt making technique, its patterns and usage, also discussed the problems in felt market, and suggested some marketing skills.

But, huge portion of data, especially those collected with Rahile Dawut's help during my field research of 2016 in Kashgar, remained unanalyzed. In 2019, during my fieldwork in Konya, another center of felt industry, I finally obtain comparative data that allows me to utilize the date I had collected with Rahile Dawut. The result is this comparative study that I would like to dedicate to my memory of Rahile Dawut and her work. Kashgar and Konya are two different cities in the Central Asia that have their own history, traditions and felt industries. Kashgar is China`s largest wester-most city in the province Xinjiang Uyghur Autonomous Region (further only Xinjiang). It is an oasis town at the rim of the dry Tarim Basin and a remarkable center of Uyghur handicraft, particularly felt. Konya is an industrial city with over two million inhabitants in central-southern Turkey and one of Turkey`s felt making centers. Felt is one of the main tourist items sold there and particularly around Mevlana museum, a central landmark in the city center.

Also, the felts produced in the two cities are different. At first sight, the felt sold in Konya is much more fashionable than the one produced in Kashgar. Despite the fact, that felt makers in Konya and Kashgar use the same felt making techniques, in Konya modern designs and patterns were integrated into the traditional felt production process and the products are sold at the city`s tourist hot spots. In contrast, felt products in Kashgar mostly serve personal purposes, they are particularly prominent in the rural context and they tend to be conservative in their patterns.

In the article, I would like to understand how it is that similar felt making techniques bring about different futures for the two regions and the people engaging in the felt making process? To answer this question, I will look at the different socio-economic contexts into which the felt making processes are embedded in the two places. I focus on the way how felt makers developed their business in Konya and pursue the additional question, why Kashgar's felt makers acted differently to market their felt products.

I will argue that as felt in Kashgar is intimately interwoven with peoples' social lives, for them, it is not only a craft but also a marker of their Uyghur identity. As such, it is much more conservative in its patterns and marketing. And it is the marketing process that is key in understanding how felt patterns were protected or developed. In Konya, the felt makers have access to good marketing structures and hence the quality of the felt products. 
Moreover, cultural, and economic exchange between Kashgar`s felt makers and other communities was rare after 1949.

For all these reasons, the techniques, and patterns ${ }^{2}$ used by Uyghur felt makers hardly changed. The felt makers in Konya incorporated modern designs and added some changes to the traditional felt making technique. This helps them to cut time in the production process and to make the designs appear more attractive for tourists. The felt business in Konya is thus characterized by high economic value of felt and felt products.

\section{The Felt Economy in Kashgar and Konya in its Historical and Contemporary Context}

Felt is a non-woven textile made of sheep fleece. It is common among the nomadic peoples of Central Asia who appreciate it for its robustness and multifunctional purposes. Kazakh, Kyrgyz, and Mongolian mobile people in Central Asia use felt as original material for their Yurts. Felt is also part of Uyghur and Turkish material culture.

In Turkish felt is called Keçe and the felt maker Keçeci. In Uyghur felt is called Kigiz. The well-known dictionary Türky Tillar Diwani lists a wide variety of different felt products: Kigiz (Eng: felt), Qayrima Qalpaq (Eng: felt hat), Yamghurluq Kigiz (Eng: rain proof felt), Képinek Yamghurluq (Eng: felt jacket), and Yamghurluq kigiz paypaq (Eng: rain proof felt socks). This list shows the importance of felt as an everyday garment in Turks' daily life. During my research in Kashgar I also encountered the Persian name for felt "Nemed" and "Nemedmen" for felt makers. Turkic languages are linguistically and historically related to Persian and thus the term can be found in Farsi as well as in Uyghur language (Bunn, 2010: 30).

Nowadays Uyghurs use felt only for domestic purposes in rural Xinjiang, whereas in Turkey, felt became a popular material to produce tourism goods and clothes. With reference to Central Asia`s mobile people the Uyghurs are settled people. For this reason, Bunn suggests, there is more pictorial evidence of their felt production than of nomadic people (Bunn, 2010: 25).

Archeological material provides evidence of felt’s long history in Xinjiang. The "Beauty of Loulan" is a 3800-year-old mummy found in Xinjiang. Archaeologists discovered her with a felt hood with woven wool lining, embellished with a feather. The movement of Turks from Central Asia to Anatolia in the second half of $11^{\text {th }}$ century was a crucial period for an inner Eurasian cultural exchange (Eiland III, 2007). During their movement they mainly used felt for make yurts (literally meaning 'felt house') because of it is easy to move. Therefore, an entire range of similar patterns on felt products can be found from Hungary to Turkmenistan (Eiland III, 2007: 268).

\section{Kashgar}

The large blue gate of Yarkend`s bazaar in Xinjiang looks inviting. The people passing the gate are freezing with scarves pulled deep into their faces. Yarkend`s winter temperatures easily drop below zero even though the town is in the desert some 200 kilometers away from Kashgar. Only the blacksmiths are sweating. The steady rhythm of their hammering almost sounds like that of a drum. I am waiting for the first customers to start to dance. The bazaar is surprisingly busy in winter. An enticing smell from the food section captivates me. A young man yells: "Come, see! This is our new silk which the Sultans used to wear in the ottoman palace 3 ". Having passed the blacksmiths, the food section, and the silk bazaar, I finally reach the felt bazaar. A colorful range of felt products is neatly laid out on a table and

\footnotetext{
2 Uyghur felt makers are using plants, fruits and some imagined pictures on felt. It is forbidden to use humans' or animals' patterns in Uyghur felt making.

3 There was a popular Turkish TV series in Xinjiang, which was called "Magnificent Century", the clothes and jewelry were very popular among Uyghurs in Xinjiang between 2013 to 2017.
} 
hung on the walls. The felt bazaar is quieter than other sections of the bazaar. Felt should charm the eyes only.

Kashgar region is a famous center of traditional bazaars where various handicrafts are traded. Those bazaars can be found in every town and they are organized and divided various parts according to selling products. Felt is one of the most frequent items sold on the bazaars. Most of the felt products, however, are bought by local Uyghurs for domestic use only. Felt is utilized in private homes to sit on to prevent more expensive carpets from exhaustion or as mattresses. The nomadic Turks of Central Asia, to the contrast, used felt products as dowry and passed it on within the family (Bunn, 2010: 50). In rural Kashgar, wall hanging felt or felt for spread on the ground is a good choice for dowry. Felt on the bazaars in and around Kashgar is only sold there but not produced. Felt makers have their own workshops in their private homes, where a corner in the courtyard, a part of the living room or in larger houses a separate room is converted into a felt workshop.

As the vignette from Yarkend's bazaar suggests, felt is a low-key product in Xinjiang but nevertheless a vital one. It is not marketed as aggressively as silk and located not as prominently as other products on the bazaar. Buying a silk scarf entails a decision-making process of whether buying this luxury item or not. It is different with felt which is a utility product that one needs to purchase anyway. Household products on bazaar's in Xinjiang are in the center. The periphery is reserved for more expensive or luxury items that require more effort in marketing. Thus, the way where felt is located on the bazaar and the way how it is marketed is illustrative for its domestic usage.

Nevertheless, the way how felt was and still is sold and marketed is also subject to political agendas. Felt makers remembered that before the republican era in Xinjiang, which was heralded in 1949, there were no permanent workshops for felt production. Instead, felt makers were wandering around, visiting various places with their tools in their backpacks. When they came across someone in need of a felt product, they marketed their services by words of mouth directly on the spot. Then, they would visit their potential costumers' houses to produce the felt item there, which allowed them to customize the final product according to the size of the customer. After they finished their work, they were paid by the costumer and left. The republican era was followed by Mao`s Cultural Revolution which forbade all capitalist activities. Thus, it was forbidden to sell felt and the felt makers had to give up being mobile traders. The official felt economy came to a complete halt. With the end of the Cultural Revolution in 1966 to 1976 felt makers erected permanent workshops in their private homes and courtyards, because they had no financial capital to start a business on the bazaars.

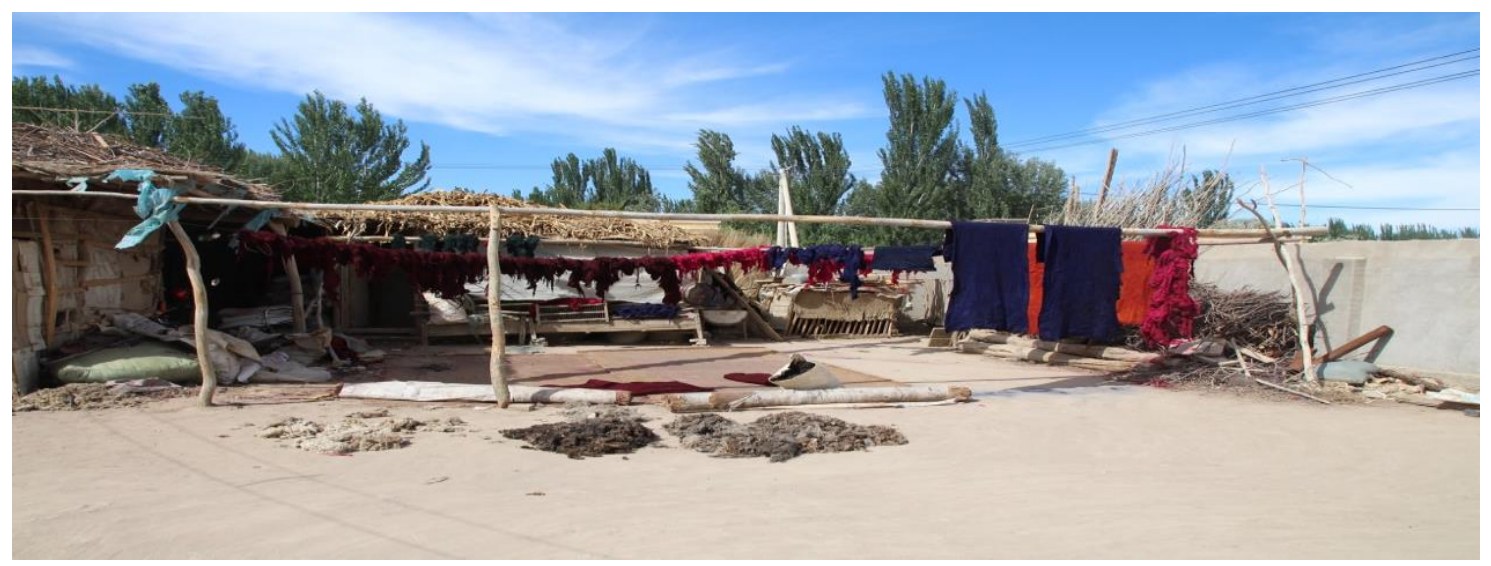

Photograph 1: A felt workshop in a private courtyard in Yarkend, Xinjiang 2017 (photo by Mukaidaisi Muhetaer). 
The price of a piece of felt depends on its patterns, colors and on the reputation of the felt maker. Qadir Axun is a famous felt maker in Qarghiliq, a small town some 70 kilometers south of Yarkend. He reminisced that his felt making skills and products were so highly valued that even other felt makers used his name to sell their felt products on the weekly bazaar. By telling their customers that this item was made by him, the ordinary felt makers could ask for double the regular price.

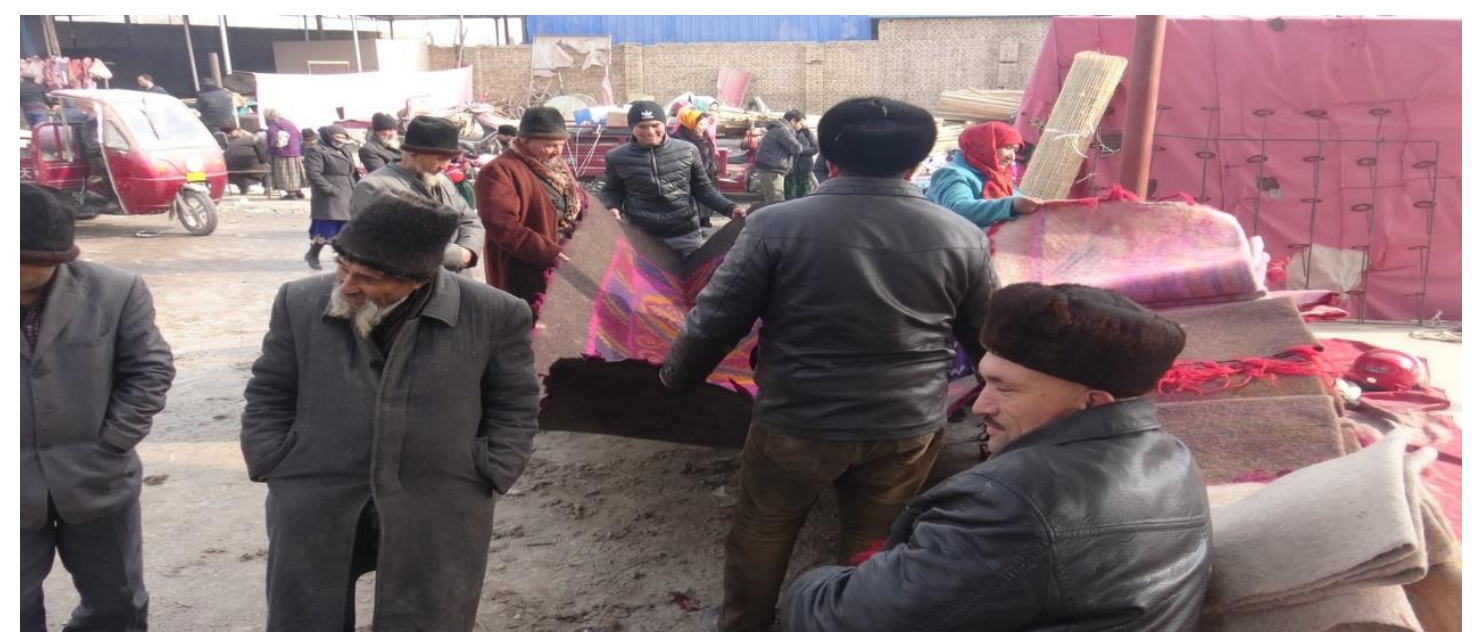

Photograph 2: Felt makers on the weekly bazar of Yarkend, Xinjiang 2016 (photo by Mukaidaisi Muhetaer).

The felt industry recovered in the 1980s, when the Cultural Revolution restrictions were abolished. But due to the extended period of inactivity, the felt makers used the old (unchanged) kicking felt techniques from even before republican era (1949), which they described as the "traditional technique". Besides, the age-old patterns, consisting of plants and geometrical shapes, are used in Kashgar. These patterns are usually bought by rather conservative (frequently purer) clientele and ignore the broad masses.

The kicking felt technique is historically well documented and it is frequently used by felt makers all over the world. In this process, after the organizing patterns of the felt is done, the felt will be covered with a straw mat. The male felt makers then (with the help of other men) kick against it with their feet. The sound it makes resembles a dull "hoo, hoo, hoo" and in some cases, the felt makers are praying during this stage to Allah for a good quality of felt.

Originally, the kicking felt technique was time and labor intensive and it required physical strength when two men need to kick it together from one side to another, and this stage is crucial for the fleece to stick and keep together. The labor intensive activity requiring special skills push the prices of final products relatively high. In order to offer felt for a more competitive price, felt makers developed machinery to ease the production process (Sabir, 1998).

Basically, three types of machines were distinguished: one for cleaning fleece (Uygh: yung tazlash mashinisi), one for pressing the felt (Uygh: kigiz xamdash mashinisi) and one for kicking the felt (Uygh: kigiz pishurush mashinisi). 


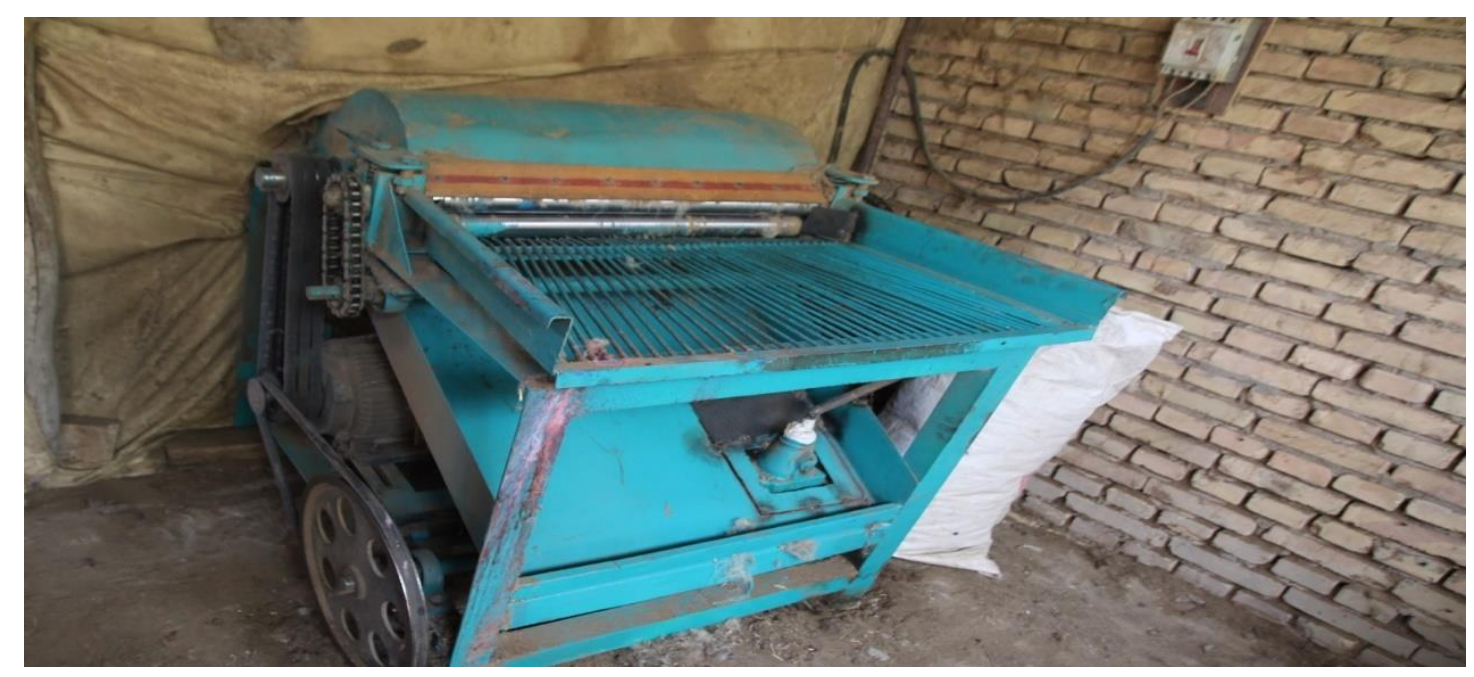

Photograph 3: Fleece cleaning machine in Yarkend, Xinjiang 2017 (Photo by Mukaidaisi Muhetaer).

The introduction and usage of the machines reduced the price of labor in felt making process. But, also the quality of the machine-maid felt is of much worse quality then hand made. Elderly felt makers always complain that the machine production had a negative effect on the regional felt making culture. They are afraid that the kicking felt techniques would disappear entirely and with it a part of their culture and identity.

The cultural aspect in the felt making process is quite strong. Before Uyghurs start the production process, a prayer needs to be spoken and the body of the felt maker needs to be washed. Otherwise, it will bring bad luck with their business or their family if they do not wash themselves or pray. The morality of felt making in Uyghur community is another unrecognized field of research. Even though felt making process, patterns and marketing of felt started to attract attention of researchers, but the morality of felt making still did not explored. The morality of felt making is a carrier of Uyghur cultural identity.

Besides, the production process mirrors the socio-political organization of Uyghur society and contribute to the division of labor within the society. The main figureheads of felt making in Kashgar are men but, in fact, it is a family business where women and children are also participating. Women are responsible for the designing the patterns and choosing the colors. These activities do not require physical strength and women are believed to have better taste for colors than men. Children participate in easier tasks, such as sprinkling hot water onto the fleece to help the fleece stick together easily.

Moreover, the marketing process is also part of the women`s business. Since 1980 most observers agree that women have withdrawn once again into the domestic sphere. Ildiko Beller-Han has argued that their participation in production and contribution to family income remains significant in the 1990s, but it remains masked and by and large undervalued (URL-3). However, women`s and children`s efforts in felt making are publicly hardly recognized in current Kashgar. They are, crucial constituents of the felt making process. The felt makers are well integrated into the social organization of the local Uyghur community. They have their own monthly felt maker gatherings and join Meshrep meetings. Meshrep is a unique performance gathering that involves music, dance, storytelling, jokes, games, ritual punishment and other performance arts; it binds Uyghur communities together in acts of social reciprocity and through the transmission of social rules and norms (URL-2). Meshrep also is an informal Uyghur institution where men socialize and educate male adolescents. Felt makers' Meshrep is a platform to share technics and information, 
educate younger felt makers meanwhile. In this way the felt makers build networks and secure social support when needed.

But, it seems to me that it is not industrialization but a lack of expertise in marketing and knowledge in designing contemporary patterns which threatens Kashgar`s felt making economy. Moreover, in these days felt products need to compete with cheap and fabric made carpets from inner Chinese regions that are often preferred by urban people who have access to these goods. All this slowly led to downgrade of the Kashgar felt industry.

The contemporary Kashgar felt makers face a limited opportunity of cultural exchange. Felt makers recognized the economic necessity to reorient their businesses and to develop and improve their felt making techniques and the marketing process. However, they are politically and economically restricted to do so. Traveling beyond Xinjiang in order to network and learn about new trends in felt production and marketing is currently impossible. Even though many felt makers feel the need and are eager to so.

Kashgar`s felt economy might be able to thrive again without giving up on traditional techniques by enhancing marketing strategies and repurposing felt. In is the Turkish city Konya that can serve as an example of a successful and ever changing felt economy that integrated modern patterns and repurposed felt by crafting it into a popular tourist item.

\section{Konya}

Loud chit-chat is sounding out of a wooden stall near the Mevlana museum in Konya. Inquisitively, I turn around the corner in order to delightfully discover a colorful display of felt hats, waistcoats, bags and shawls hanging inside the stall. There is a man sitting on his stool while a woman excitedly discusses felt patterns with a customer. The woman`s friendly but convincing selling strategy yields fruits: The customer contentedly purchases a whole bunch of felt products. Mehmet and his American wife Theresa approach me with a cup of hot tea. They are curious what I am looking for. When they learn about my research, they hand me over a cute felt bag with animals on it, reassuring me, that it would bring good luck for my research. Indeed, the felt bag from Konya became my favorite piece: It is a robust product suited for everyday use, very soft, no uncomfortable sheep smell and on top of it, felt products there look fashionable with its attractive black and white pattern.

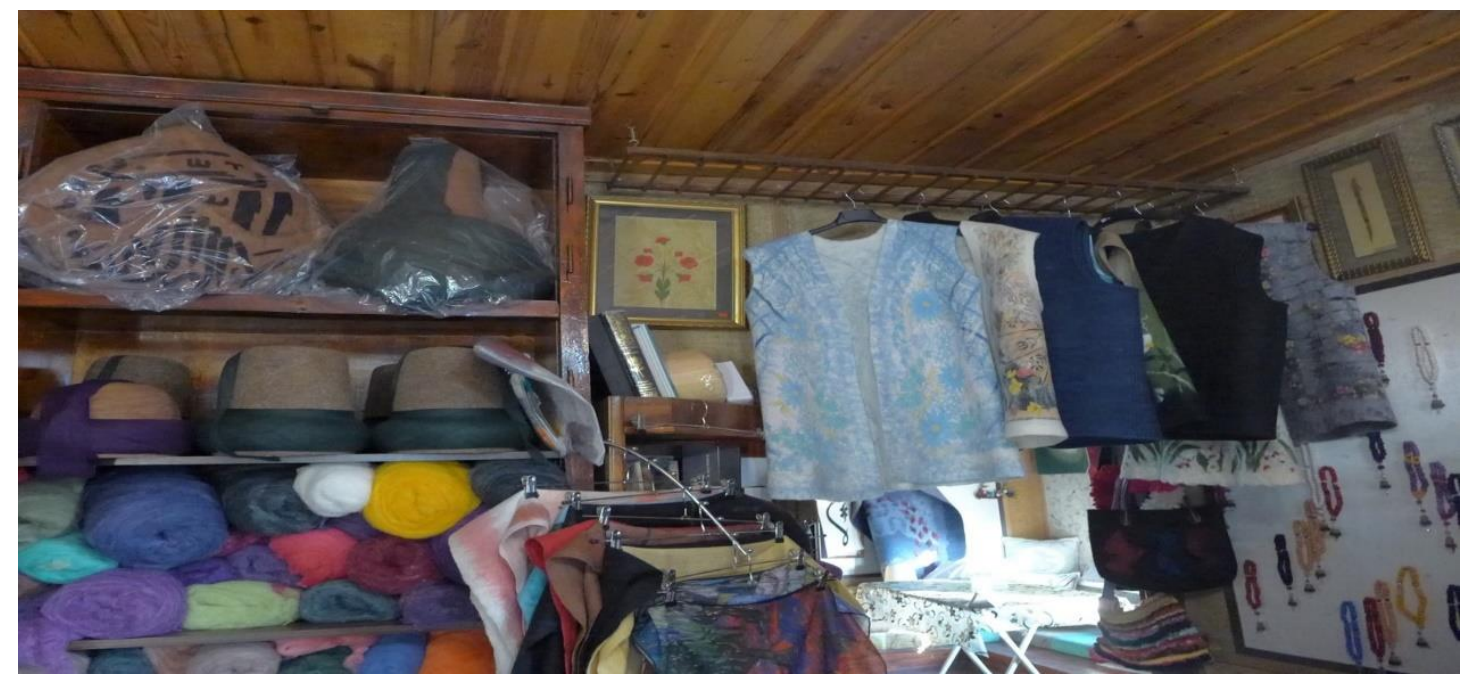

Photograph 4: Mehmet and Theresa`s felt shop near the Mevlana museum in Konya 2019 (Photo by Mukaidaisi Muhetaer).

The Mehmets and Tereza shop is very near of Mevlana museum, a tourist hotspot in Konya`s city center. As part of his family tradition, Mehmet learned felt making at the age of 13 from 
his grandfather. In 2010 his felt workshop was "awarded as one of the seven Turkish Living Treasures by UNESCO and the Turkish Ministry of Culture and Tourism" (URL-1). In 2019 he led his felt workshop in cooperation with his wife. Together, they design felt products with modern patterns and unconventional colors and sell them in their workshop. The workshop, however, is not only a sales booth but at the same time serves as a platform to teach and introduce their felt making technique with their machines to people from all over the world. When passers-by stop to watch the process, he is telling them about the history of felt and how his family came to develop their felt business.

The kicking felt technique almost disappeared in Konya (Çeliker, 2011). As in Kashgar, also in Konya the technique vanished with the introduction of new machines. But, the development of Konya`s felt economy, however, took a remarkably different direction than that of Kashgar. There were several reasons for this.

Firstly, the Turkish government supporting felt making in Konya. The Turkish Ministry of Education teamed up with local felt makers and sending students from Selçuk University to Konya in order to learn about the history of felt making and its production process. The students design their own pieces with different patterns on the ground while the felt makers cooperate with lecturers at the University. The experienced local felt makers give presentations to introduce felt making to the students in seminars. At the same time there is a cooperation between felt makers and the Konya museum which offered to display their art work.

Secondly, Konya`s felt makers incorporated modern designs and patterns into their felt products while felt makers from Kashgar relied on their memory of traditional patterns. For example, in Konya, felt makers use horse and other animals' patterns, meanwhile use "blue eyes ${ }^{4 "}$ patterns on their felt products. Konya`s felt makers also worked with notable designers, such as Selçuk Gürışık who integrated the felt designed and produced by local felt makers into his international fashion shows. Felt, thus, became an symbol of Turkish art and culture.

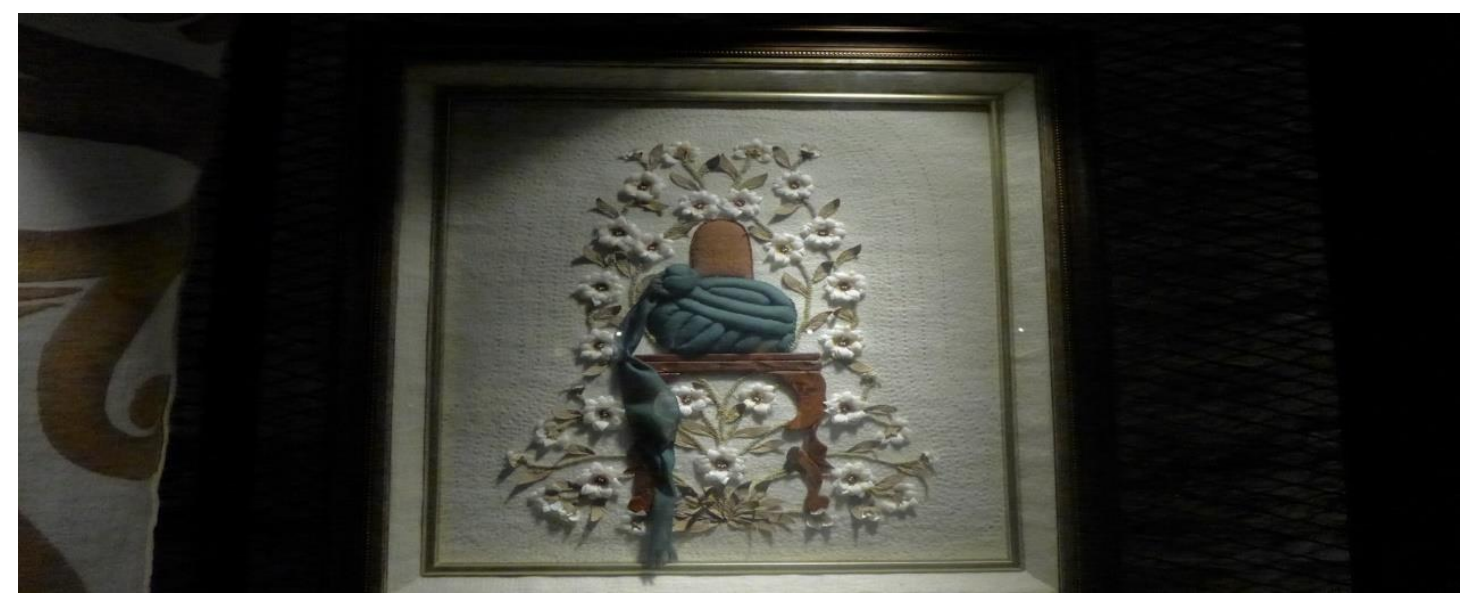

Photograph 5: A n art table made with felt, Konya 2019 (Photo by Mukaidaisi Muhetaer).

With the support of the Turkish government and the eagerness of the felt makers to incorporate contemporary designs, Konya turned into a thriving center of Turkey`s felt economy.

\footnotetext{
${ }^{4}$ Blue eyes- Nazar Boncuk in Turkish, which known as can protect people from evils.
} 


\section{Conclusion}

The analysis of felt making in Kashgar and Konya illustrated the different development of the felt economy in the two places. I showed how the different settings of the felt makers and their businesses affected their marketing processes and sales quantities. Felt makers in these two regions are using same technique but having different marketing structures, it caused two different developments of felt products. Also, the governmental support works important role in felt making technique, its knowledge transfer system and market. The felt making process is complex and every step incorporates Uyghur conceptions of social and moral value. It is thus an inseparable part of Uyghur identity. Every amendment to the felt making process entails a renunciation of the inscribed social and moral order. For this reason, Uyghur felt makers were reluctant to intervene into the process of felt making. The price and value of felt in Kashgar, however, dropped considerably after the Cultural Revolution. The felt makers were in economic need and thus forced to reconsider the felt making process as it was handed over by their ancestors and reconsider their marketing strategies. The political development in Xinjiang, however, currently does not allow them to seek for inspiration beyond local borders. This research analyzed the marketing skills and current situation of felt making in Kashgar and Konya, but its knowledge transfer system, the social life of felt makers and their relationship with family members, women's role in felt making still need to explore with different anthropological approach.

\section{References}

BUNN, Stephanie. (2010). Nomadic Felts. Brithish Museum Press.

ÇELİKER, Deniz. (2011). “Germiston Günümüze Türklerde Keçecilik ve Keçe Yapımında Yeni Teknikler”. Süleyman Demirel Üniversitesi Güzel Sanatlar Fakültesi Hakemli Dergisi.

GÜR, Semra. (2012). "Felt-Anatolian Cultural Value: Being Changed Into an Art Object". Betaman University Journal of Life Science, Vol. 1.

Mehmud Qeshqeri. (1981) Türkiy Tillar Diwani. Vol. 1-3, Ürümqi: Xinjiang People Publish House.

Murray Lee Eiland III. (2007). "Felting Between East and West". Visual Anthropology, Vol. 20:4, pp. 263-283.

SABİR, M. (2009). Kigizchilik.Ürümqi: Xinjiang People Publish House.

\section{Internet References:}

*URL-1:http://www.turkishculture.org/whoiswho/turkish-traditional-art/feltmaker/mehmet-girgic-675.htm (Access: 14.11.2020)

*URL-2: Harris, Rachel. (2020). "A Weekly Mäshräp to Tackle Extremism”: Music-Making in Uyghur Communities and Intangible Cultural Heritage in China”. Ethnomusicology 64, no. 1 (2020): 23-55 doi:10.5406/ethnomusicology.64.1.0023 (Access: 15.12.2020)

*URL-3: BELLER-HANN, Ildiko. (1998). "Work and Gender among Uyghur Villagers in Southern Xinjiang", Cahiers d'études sur la Méditerranée orientale et le monde turcoiranien [En ligne], 25|1998, mis en ligne le, consulté le 15 décembre 2020 http://journals.openedition.org/cemoti/55; DOI: https://doi.org/10.4000/cemoti.55 (Access: 15.12.2020) 